\title{
Research on the Current Situation of China's Internet Financial Risks and its Preventive Countermeasures
}

\author{
Liduo Zhang ${ }^{1, a}$ \\ 'Zaozhuang University, Zaozhuang, Shandong Province, 277160, P.R.China \\ a22441188@qq.com
}

Keyword: Internet finance; Internet financial risk; Supervision; Preventive countermeasures

\begin{abstract}
According to the introduction of Internet financial risk, this paper mainly use literature review and qualitative analysis method to make a detailed analysis of specific Internet financial risks in order to suppress them, and provides forward targeted Industry supervision strategies and risk preventive countermeasures. The conclusion is that it is very urgent to suppress the Internet financial risks in our country at present.
\end{abstract}

\section{Introduction}

Internet finance is the frontier of the Internet industry and the traditional financial industry, which is combined and permeated with each other. Its emergence is not that the Internet completely subverts the traditional financial industry, but the Internet has expanded the development space for the financial industry. Financial institutions can provide better financial services for customers through the Internet technology. At the same time, the financial industry also provides a new financial profit model for the Internet enterprises, making the Internet enterprises close to the financial institutions. Usually, it is often explosive and rapid development in the early stages of the industry, accompanied by the industry very immature and unstable, various risks gradually accumulated and released at any time, the negative influence is increasing, with the vacancy and legal regulatory system, and makes the risk avoidance and prevention efforts are facing severe challenge.

\section{The Main Risk Types of Internet Finance}

Risk of Regulatory System. Internet finance is a complex industry which is generated by various industries such as finance, Internet and information technology. It involves a lot of fields, which brings great difficulty to the relevant financial supervision departments. This may be related to financial institutions, can also be the Internet enterprise, but current Chinese legal supervision's main body and related responsibilities, including the establishment of national banking law, securities law and insurance law, are limited to traditional financial institutions, which is impossible to cope with the explosive development of Internet financial enterprises. In the context of the absence of supervision, the direct regulatory body is still not clear in the industry, as a result, the risk gathered gradually and ready to burst at any time, which is based on the Internet financial business scale expansion, the enterprises concerned crazy disorderly competition, and the exponential growth trend of product types and amounts.

The Risk of Lack of Law. Internet finance is emerging industry in recent two years. Due to the short history of the industry, the current legal supervision system appears almost blank, which includes regulatory gap, threshold gap and standard gap. Since the regulatory body involves multiple government departments, the most direct regulatory body is not clear enough so that a set of effective legal system cannot be timely and effective in order to constrains the Internet financial industry. Because of the lack of legal constraints, many Internet financial enterprises and their related business and products have been wandering between "legal" and "illegal". Regarding the rights and obligations on the Internet, the relevant provisions are not clear, reasonable and perfect, even some laws and regulations are nominal on Internet financial contracts. In the event of breach of contract, it is easy to have disputes between rights and liabilities. 
The Risk of Information Security. The most obvious advantage of Internet finance is high efficiency, low cost and no restriction on time and space, however, there are various kinds of information security risks exist at the same time. In addition to suffering from some common problems of information security, sometimes the business transactions are unable to identify the legal status each other. On the one hand, some customers use a non-real name to deal with the real name system, on the other hand, some Internet financial enterprises are not good at customer identification, and the transaction records are not properly preserved, and the transaction is not systematically managed. At the same time, there is a lack of security protection mechanism for the real information of customers, with the highly virtualization of Internet finance, therefore, the authenticity of some transactions cannot be examined and verified.

Operational Risk. It refers to the risk of loss caused by internal system defects, negligence of personnel, or external events (hacker's malicious attacks). It is reflected in two aspects. One is the third party payment platform is vulnerable to financial losses by hacker attacks, it is easy to steal and cheat the money from internal personnel as well. The other one is the loophole of Peer-to-peer lending platform construction, resulting in the leakage of information and the loss of Internet loan. Peer-to-peer lending mainly services to small and micro enterprises and individuals, and their credit status is poor compared to the borrower of a commercial bank, and the audit process easily hidden risks.

Liquidity Risk. It refers to the uncertainty of Internet financial companies to obtain sufficient funds to face the liquidity needs within a certain period of time. The Internet financial liquidity risk mainly represents in the following three aspects. First, because the third party payment platform does not pay the client deposit reserve, it needs the platform to advance the funds which are redeemed by the customer. If the short time large-scale redemption occurs, the payment platform will face the liquidity risk. Second, because peer-to-peer lending platforms and small lending companies mismatch assets and liabilities, it generates liquidity risk. Compared with commercial banks, Internet banking is short of deposit reserve and risk assets provision, and lack of experience in dealing with liquidity problems. Liquidity risk is more harmful to them.

\section{The Specific Risk Analysis of the Main Mode of Internet Finance}

Third Party Payment of Risk. The main risk of the third party payment platform comes from three aspects. The first is the subject qualification and the risk of the scope of operation. Although it is the positioning of the intermediary network collection and payment, actually it is more like a settlement business by providing guarantees and gathered a large amount of money in a temporary platform, this function is similar to bank deposits. At the same time, those platforms can directly control temporary funds, which can easily lead to the separation of funds from supervision and even the possibility of embezzlement except for some large platforms with special accounts that do not participate in customer exchange. The second is money in transit and the virtual account funds to precipitate the risk. In the process of payment, the third party payment institutions are engaged in capital storage and fund deposition. When a certain scale is reached, they will generate capital security and payment risk if there is no effective liquidity management. Three is the risk of money laundering. Because the Internet financial transactions mostly are through the Internet and telephone transaction, has the characteristics of rapid, concealment, convenient, The bank is unable to get a thorough understanding of the customers, which determines the identity of the customer and the identification of suspicious transactions, transaction information, financial activity detection and other daily anti-money laundering work, cannot be effectively implemented, even cannot deal with the flow of funds to carry out real tracking, can easily lead to the risk of money laundering.

Internet Credit Risk. Peer-to-peer lending is mainly focus on Internet credit risk, which is derived from the risk of regulatory system and the risk of lack of law. In recent years, a significant number of Peer-to-peer lending platforms go bankrupt or escape with money. This extreme situation is caused by low industry threshold, regulatory gaps and lack of law. In the actual situation, there are many Peer-to-peer lending platforms are not good at risk control, but expand business scale blindly. Once the Internet loans are overdue, it will lead to a large amount of loans that have not 
been recovered. The companies' capital turnover face difficult, and unable to pay investors on time, and even original intention of some platforms is established in order to have an Internet fraud.

Crowdfunding Model Risk. There are three common risks: one is the "feedback" risk. Simply speaking, crowdfunding provides a display platform, so long as you can find enough like-minded people to pay for your creativity on this platform, which can satisfy your demand, and your ideals will be realized. However, the key of the problem is that creativity can be realized, or it may just be "Utopia". If the fundraiser's creativity or product fails, it means that the promise cannot be fulfilled to investors, so that the risk of "feedback" will break out. Two is the "infringement" risk. It has double meanings as follow. On the one hand, the initiator's project may itself be suspected of violating other patents, but the asymmetry of information makes it difficult for investors to understand the real situation of creativity or products. It is difficult to estimate the disputes between rights and liabilities arising from the outbreak of this "infringement" risk; on the other hand, Under the premise of the lack of public patent related intellectual property law system, once the sponsor's project is displayed on the crowd raising platform, its unprotected creativity is easily plagiarized by others, resulting in the loss of novelty and the loss of competitiveness. Three is the risk of "fraud". The motivation of the project initiator is impure. After running the public financing project, the case of running is not rare. At present, some publicly funded websites are hard to provide regulatory guarantee and risk control.

\section{The Internet Financial Risk Prevention Strategy}

The Basic Strategy of Industry Supervision. China should establish a unified Internet financial supervision system. The traditional decentralized regulatory model will make Internet finance free from the current regulatory system. First of all, the main sector should set up a functional oriented supervision division system, from traditional "institutional regulation" to "functional separation supervision" and "mixed industry coordination supervision", so that the Internet financial industry can be effectively incorporated into the regulatory system. The business scope of related businesses should be combined, on this foundation, we should clarify the regulatory departments of enterprises and businesses, clarify the main body of supervision, and also turn from asset and liability management to the liquidity of capital, the safety of financial transactions and the protection of customer information. Secondly, we should establish a coordination mechanism between the financial regulatory authorities and other regulatory authorities based on the areas covered by Internet finance, and create a unified data platform for Internet finance, with a clear understanding of the division of labor and cooperation mechanism.

China should establish a perfect legal system and standardize the Internet financial business. Firstly, the regulatory authorities should set up a comprehensive and standardized laws and regulations as soon as possible, and incorporate the new Internet finance mode such as P2P network credit and crowdfunding into the legal supervision system, clarify its legal status and strictly stipulate the scope of business. Secondly, it is to improve the construction of Internet financial basic safety law, involving the legality of e-commerce, the safety of electronic transactions, the protection of personal privacy information, the validity of electronic certificates and digital signatures. Thirdly, it is to speed up the formulation of the national standards and rules and regulations of Internet financial technology, so as to standardize the third party payment, identification and verification of customers.

China should strengthen the construction of the self-discipline system in the industry and strengthen the self-discipline of the industry. The healthy development of the Internet financial industry can't rely entirely on the mandatory management and restriction of the government supervision entities. Industry self-regulation can be an effective complement and improvement of government regulation. At present, the China payment and Settlement Association and some institutions have already formed the Internet financial Specialized Committee. Similar industry association was founded, on the one hand can promote interbank exchange, explore innovation mode, and promote the sustainable development of Internet banking; on the other hand, it can further improve the self-discipline mechanism, guide the members of the committee to strengthen 
enterprise's internal control, and regulate specially for compliance management, risk management, financial transaction security and the protection of investors, and maintain fair orderly market competition.

Speeding Up the Development of Internet Information Technology. Internet finance is an industry based on the Internet information technology. First of all, China should establish a unified Internet financial information technology standard system based on the international standard of Internet security. Secondly, China should integrate business related information, and establish database based on customer transaction information, and analyze business data to achieve full monitoring of business process. Finally, China should energetically develop the information technology of independent intellectual property rights, strive to make significant breakthroughs in network security technology, and reduce the serious dependence on foreign hardware and software.

Taking the "PRISM" eavesdropper in 2013 as an example, the event highlights the importance and urgency of the research and development of the independent intellectual property of our country. The event display center server safety related departments in the United States directly into the American Internet Network company in data mining, gather information, requires all computer hardware and software products in a back door, even forced part of telecommunications and Internet companies to provide users personal information and data communication. One of the main results of the "PRISM" event is to push China to speed up the pace of independent research and development of information technology.

Creating an Internet Financial Universal System. Although Internet finance is developing rapidly, most ordinary people do not know clearly about the nature of Internet finance so that their investment risk awareness is very weak. It is necessary to strengthen the education of Internet financial knowledge. First of all, to raise the public awareness of the nature of Internet finance, Internet finance has not changed the attribute and function of finance, investment is still the main function of lending, payment and settlement, which is essentially a model of financial market innovation, did not go beyond the scope of the existing financial system. Secondly, we should raise awareness of the financial risks of the Internet. Internet financial risk is everywhere, whether investors or lenders must be careful disposal. Many investors invest a lot of money in the field of Internet Finance in order to gain high returns, but few people are aware of the risks behind it. There are also investors who blindly believe the power of the platform and bet the desire for financing on the platform, which result in missed other the financing opportunities and even the loss outweighs the gain. At last, we should improve people's moral level, improve people's credibility and integrity through knowledge popularization and spread, which is related to the future of Internet financial development.

\section{References}

[1] Q.W. Xu, X.F. Zhang. The risk and supervision of Internet finance from the essential features[J]. Financial Theory \& Practice, 2014(7):64-68. (in Chinese)

[2] X. Zhang. Internet Finance: model, risk and its prevention[J]. Journal of Harbin Finance University,2014(4):14-16. (in Chinese)

[3] M.Y. Li, L.J. Lv. Current situation and supervision strategy of Internet financial risk in China[J].Economic Review,2014(8):87-91. (in Chinese)

[4] G.Z. Wang. Internet financial risks and Countermeasures[J].Hebei Enterprise,2013(11):42.(in Chinese)

[5] D.W. Chen. The current situation, and countermeasures of Internet financial risks [J]. Hainan Finance,2014(10):67-71.(in Chinese)

[6] G.Z. Yao, G. Zhao. Internet finance and risk control[J],Journal of Nanjing University of Posts and Telecommunications (Natural Science Edition),2015(4):9-21.(in Chinese)

[7] Z.H. Li. Research on Internet financial risk and its prevention in China Times Finance,2016(12),41,59

[8] P. Xie, C.W. Zou. Research on the Internet financial model[J].Journal of Financial Research, 
2012(12):11-22.(in Chinese)

[9] S. Zhang, J.W. Shi, D. Lei. Research on operational risk management of Internet finance[J].New Finance,2013(9):33-36.(in Chinese)

[10]Z. Li. Internet finance: Endogenous risk and legal logic[J].Wuhan Finance,2014(5):35-57, 69.(in Chinese) 